\title{
都市の緑地保全思潮に関する研究（その 2)
}

一一成長期に拈ける保全論一

\section{白井彦 衛* \\ Study on Current Idears of Green Space Conservation in Cities (2) \\ -Conservation Theories in the Growing Era- \\ by Hikoe SHIRAI*}

\section{1. 緑地保全論の系譜 (1)}

大正時代に和计万緑地論の萠芽を経て，昭和時代に入 ると緑地論は成長し，保全の思想が一層明瞭になる。そ の成果を，大屋䨝城，太田謙吉，北村徳太郎，関口鍈太 郎，永見健一らの論文に見ることができる。

\section{1 成長期初頭にみる論調}

（1）緑地論の定性化・定量化への試み

成長期に入り緑地の保健衛生的効用および必要面積に ついて最初に論じた人は大屋䨝城である。氏は昭和 4 年 (1929)，「衛生施設としての公園の価值」を機関誌「都 市公論」に発表，これはその時点において公園・緑地の もつ保健衛生上の効果を論じた最も詳細かつ論理的内容 をもつものであった。その作用を，

物理的作用 塺埃やバクテリヤの防止，空気の瀘過

化学的作用 炭酸同化作用，オゾンの発生

としたが，当時化学的作用については不明な点が多く， 当面期待できるのは物理的作用であるとし，海外の事例 を引用しながら，気温緩和，清潔な環境の保持について 述ベた。

また翌 5 年 (1929) には「都市の公園面積」を同誌に 発表，当時関係者に流布していた公園の必要面積がく都 市面積の $10 \%>と い \zeta$ 説は，行政区域が市民の利用範囲 と一致するものでないから，人口を標準として公園面積 を決めることが妥当であり，人口稠密な都市洼ど公園が 必要である，と主張した。これ以降学界では面積率論に かわって人向当り墖が主流となる。

なお，大屋は緑地の用語注用いず，一貫して公園で通 しているが，海外の例として Grunfläche があり，樹术 被地と解されるという見解を示していた。

(2) 欧米の緑地論の研究

大屋につらいて緑地の必要量および機能全般について 研究を続けた人は，永見，関口，北村らであった。永見 は昭和 7 年 (1932) 九州大学に拈ける講義録をま之め, 「(理論実際) 造園学」を出版，世に問らた。氏は，H． コッホの説から自由品地と緑地とは区分されるべきであ

* 千葉大学園芸学部造園学科
るとし，さらに風景の保護・保留および開発について言 及した。本書はまた個人による造園学総論の最後を飾る ものであった。

関口は第 1 次大戦後に出汁る欧米の緑地問題の進展に 着目し，海外の文献を多く涉猟するとともに，欧米の緑 地思潮を紹介した。その論文の多くは昭和10年から同30 年代にわたる。とくに注目されるのは昭和 6 年 (1931) 日本農学大会造園部会に拈いて，「現代都市公園面積に 関する各国の学説」として，M.ワーグナー， P.ウオル フ，J．ブラント，J．スチューヴェン， C. L.ペプラ 一, F. F.シャートレフ, L. L.ブロック， T.アダム スの学説をとりまとめて発表しだ)。

（3）公園計画原理の展開

北村は萠芽期から緑地論を発表していたが，M．ワー グナ一の緑地計画基準をいちはやく紹介して以来，独自 の立場からも公園の必要理由, その分類，その計画理論 を「都市公論」に 3 年間に10篇続けて発表した5)677)。

その必要性について，保健衛生的価值および余㗇利用 価值の両面があるとしながらも，前者については大屋の 所説に及ばず，後者についてはとくに戸外余䀦の重要性 について事例を引用しながら詳細に述べた。またその分 類について，公園たるべきものはく営造物〉であること が基本であり，地域制をとる国立公園とは峻別すること を指摘，緑地ま市空地と称して，その種類を公園，公 開園地, 共用園地, 遊園地, 私園地, 保存園地汇区分乙 た5)6)

その計画理論については，都市面積に対する必要面積 率によるのではなく，1 人当り所要面積を妥当とした点 について大屋と同様であるが，欧米の諸説と対比しなが ら，わが国にあるべき公園理論を展開した。すなわち所 要面積算出の基礎として年令別，施設別，活動面積，利 用時間, 使用回数, 1 公園当最小面積, 誘致距離, 公園 の種類について条件設定を行い，結論として公園必要面 積を求めるための第 1 段階である全市民 1 人当りの運動 場所要面皘を 1 坪 $\left(3.3 m^{2}\right)$ と計算し，さらにその他に都 市公園・修景園地を前記の運動場同様 1 坪, その他に自

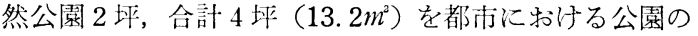


所要面積とした6)。ただし，運動場所要面積算定の詳細 さに比して，北村自身が涩めているように他の都市公 園，自然公園の算定論拠は極めて稀薄であり，かつ今日 的観点からなる緑地保全上の配慮は決して强いとはい光 なかった。

\section{(4) 公園機能論の反省}

上述のように，啝和に入ると数年間，都市公園に携わ

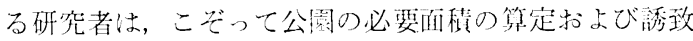
距離の適正值を嶈きだそうと努力し，その成果が誌上に 発表されたのである。その傾向に対して，田村剛は昭和 6 年(1931)「都市公論」の公圆特集号に沶いて，都市公 園関倸者による数字の遊戯に与ぎず，市民の要求にいか

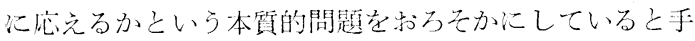
敩しく批判した。田村の発言は，たんに利用原単位の否 定ではなく，欧米と日本の生活様式の相違が，彼の国の 諸元の直輸入では通用しないことをも含んでいる ${ }^{8)}$

都市公園関係者に対与る田村のえらな直言が数多くあ った訳ではないが，赫りしも国立公圆法制定をめぐる気 運が高票るなかで，緑地をめぐるく都市的〉く自然的〉 の考光方の相違は造橉界にかなり広く双られたこともま た事実であったといえよう。

\section{（5）国立公園誕生の経緯}

ここで国立公園法の制定をめぐる経緯を一瞥すること は，当時の些溒界の動问を知るために重要である。

国立公㱖創設への始偊は，与でに明治の末期に少いて 多られるが，法制定への具体的な動きか十は，坚和 2 年 （1927）に国立公園協会の設立，さらに湖蚛之輔，筧正 太郎，本多静六，日村嗍ら他に林学系の有志により，国 立公園の必要性が唱えられ，また東京・大阪の報道機関 により日本八景が選定され，PR活動が盛んとなった。 その後, 同協会の建議, 調查会による制度および選定力 針の審議を経て, 同6 年（1931）4月, 法律36号をもっ て公布，同10年 (1935）年10月法の施行をみた9。この ような背景のもとに，林学系の多くは自然公園老志向し た。また農学系隹震災復興公園事業に実績を重ね，大勢 として都市の公園・緑地を志向することとなった。

\section{2 林学系・農学系の人事交流}

以上の経緯の中で，究極には国土と都市の自然的，人 為的な環境の保護・保存, 保全, 創造を目途とする造園 界の健全な結束をはかる動きが 2 回にわたって試みられ た。

第 1 回目は昭和 8 年（1933）の初頭，本多のもとに両 者の有志が一同に会し ${ }^{10)}, 1$ 時期沈滞していた在来の学 会を改組し，農林一体となった新学会を発足させること とし, 同年 6 月本多を学会長に推挙し, 翌 9 年 (1934) 機関誌「造園雑誌」第 1 号をだし現在に至っている11)。

第 2 回目は，昭和13年（1938）とみられるが，行政面 について依然として林学の自然公園指向, 農学の都市公
園指向が強すぎるため，田村風と北村㯖太郎は両者の人 事交流を盛んとすることにより，上述したギャップを解 消しようとの紳士協定を結んだといわ扢る12。ここで紳 士協定と称与るのは，国の人事が涸人間で決められるべ きものでなく，両系列に対してあくまでアドバイスで善 処しようとしたことによる。したがってこれについて

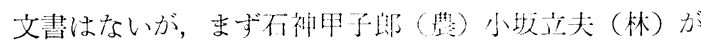
人事交流したことにはじまり，石原耕作（林），掯畞哲 雄（林)，二上兵一（地）与代交流の対集となり，各人

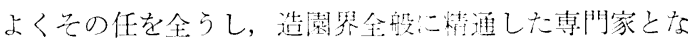
りえたのである13。

\section{2. 緑地計画の進展}

成長期としての査証は都市計画主任官会議に扮いて緑 地基準が採択されたことに流じまる。この当時は前述の 都市緑地をめぐる機能論, 計量化論が盛んな時勢であっ た。つづく東京緑地計画はわが国に赫いて本格的な緑地 計画の樹立であった。これが主動因之なり，緑地保全思 想の開眼となる。

\section{1 主任官会議と緑地基準}

昭和 2 年 (1927) に開櫵导竌た全国都市計画主任官会 議は，はじめて公的に緑地しい5用語意使用し，かつ公 園の面積摔を土地区画整理審查標渠の中に規定した点で 重要な意味をもつものである。同会墥沈4月11日より同

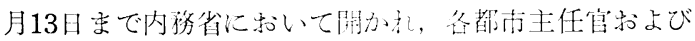

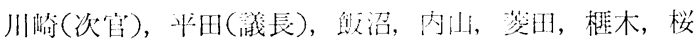

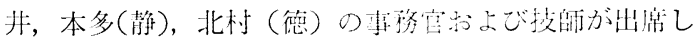
た14)。

緑地計画上注目される記述法，士地区西整理審查基潐 に㐫る設計基準にく緑地〉といら項目が明示され，イ） からト）まで 7 件の基準が示されていることである。す なわち,

イ）公園敷として施行地面積の $\dot{3} \%$ 以上を留保するこ 之

ロ）前項の敷地は之を適宜近隣公園, 昌童公園として 配置すること

八）各公園の位置，形状，面積等は利用者の状況及豫 想設計を考慮して之を定むること

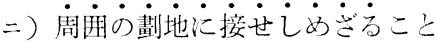

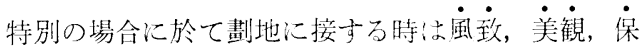
安の関係を考虑すること

ホ）児童公園及幼児公園の配置に就ては各項に注意す ること

1. 交通頻繁なる道路，軌道又は河川に依り来往を 妨げられざること

2. 小学校及其の運動場と関連して考虑すること 一）街路樹, 前庭, 庭園, 貸付㻃園, 不利用地の植栽 等に付適当に考慮すること 
ト）風致ある土地に付ては前号の各事項は特に注意す ること

の諎項目である ${ }^{14)}$ ここで注意すべきことは，緑地の設 計基準を沈めたとはい光，父の実態は公園で㐫り，吏だ 保全の思想も时踓でないが，施行地㑔䅡の3\%公園留歩 の決定が現在に至るまで生きつら゙けたことである。なお この基淮の作成は，当時内務省の北村（德）の手腕に上 るとされている14)。

しかし、䛉の $3 \%$ 留保が耕地整理法第 1 条の事業籁阴

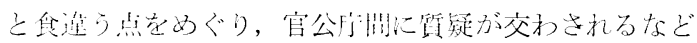
して，この基準が直ちに土地区、酒整理事業に反咉された わ外でなく，昭和 2 年から间 8 年江至る間，全国上地区 画獘理事業施行面積のらち，公園の留步面積桼は 0 〜

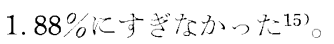

炤和 8 年 (1932) 7 月，次官通澾（都発第15号）によ

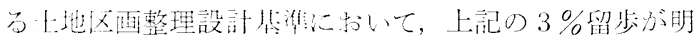

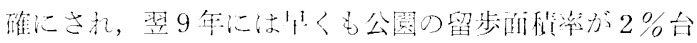

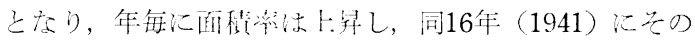
面稓流は3\%に这したのである1516)

\section{2 東京緑地計画の経緯とその内容}

(1) 経 緯

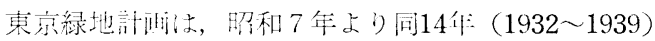

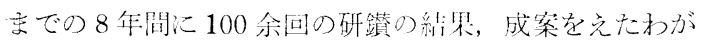
国で最初のから本格的な緑地計凷である。同計画の策定 飞先だち, 阔 7 年 8 月 15 日, 飯沼一少 (内務省都市計迪課

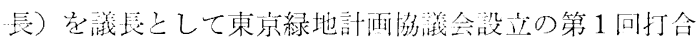
せが阔かれ，同年10月10日同永誐会は正式に発足した。 会長は内務次官とし, 委員注内稀省都市計画課, 都市汁 画東京地方委員会, 東京府警視庁, 東京市の各職員拉上 び学識経験者であった。原案の検封は, 関倸官公署当事 者汇上る幹事会がその任にあたり，1緑地の分類，(2) 線 地計画区域，(3)緑地の基淮，4緑地計画案の作製，(5)緑 地の实現関する各事項の検討を5ケ月にわたって行っ た

同 8 年（1933） 1 月 25 日，東京緑地計画協議会第 1 回 総会を開催，前記の翰事会汇より上提されな原案が協議 された。この会議の出满者37名中, 造園関係者は夰下清, 丹羽鼎三, 北村德太蚛, 遠山信二, 水谷駿一 (以上議席 番号順)で尔る ${ }^{1718) 。 ~}$

(2) 緑地の分類

会議はまず緑地の意義について概念規定*を行ない, つづいて県案の緑地分類についての議事があった。すな わち議事録に上れば，緑地を(1)社会緑地，(2)利用緑地， (3)緑地汇準ずる方市，の3 種類に大別した。

* 緑地卜八其ノ本来ノ目的ガ空地ニシテ宅地，商工 業用地及頻繁ナル交通用地ノ如ク建蔽セラレザル 永続的ノモノヨ謂フ
社会緑地はイ）公園，口）公園に隼ずるもの，分）墓 苑，二）公開緑地，木）共用緑地，一)遊園地からなる。 この範ち的らに属与る事例として界隈公園（幼児公園，

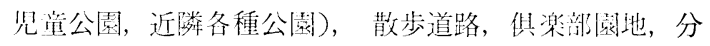
以、園という新語が生れる。

利用緑地と虾農林栄用地を意味与。

緑地に準ずるものとは庭園拉よび保存地(法律命令に 上り自然状態の保存也られる土地）で放る17。

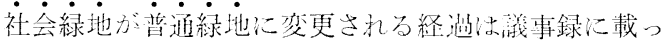

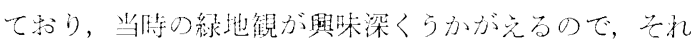

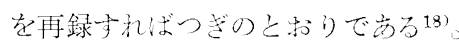

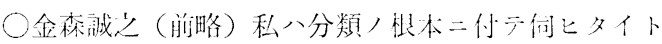
思ヒマ久, (中略) 社会緑地, 利打緑地, ソレカラ緑地 ニ準ズルモノトカ云フナウナ大別ニナッテ居りマスガ,

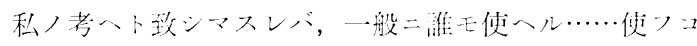
卜ノ计来儿緑地，ソレカラ特定人デナケレバ使つロトガ

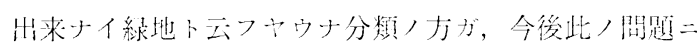

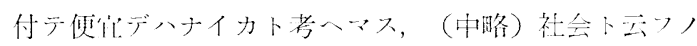
八何ダカ特別)字句二使ハンル文字デアルト照上マ久カ ラ，社会綠地下云フノョ般緑地下スルノガヨイカト思 ヒマスガ。

○中島清二後, 方, 利角緑地卜云フ, 又八生産緑地ト云フナウナ言葉デ八恶イデスカ，(後略）

○北村德太郎 商聴モ紹構デスケレドモ利用ガ慣用語 ニナリッッアル様ブス。

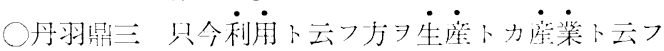
意味二改メルト云フ案ガ出タヤウデアリマスカ，大変結 構ヂヤナイカト琹ヒマス，（後略）

このよらな颃疑経渦の中で, 北村, 井下は原案化賛成 しながらも，小羽が金森，中鼠の変更案を支持し，さら 飞西村(耀一)が一般緑地を普通緑地となる考光を述心，

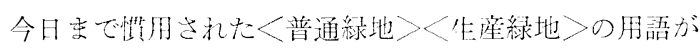
誕生したのである18)。

つきに同 8 年（1933）12月に決定した緑地の分類を表 示与る ${ }^{18)}$ 。の分類は当時沈もちろ九，戦後昭和 40 年代 に至るまで使いられた。

その後さらに 5 年間にわたり, 景園地, 行楽道路, 環 状緑地带, 大公園, 運動塕, 自然公園のフイジカルな策 定段階を経て同13年末に核成案を得た。

(3) 計画の内容

昭和14年（1939）４月作成された東京緑地計画の内 容はつぎのと妨りである17)。

(1) 景園地 合計 (37力所, 289, 143ha)

東京府 (12力所, $96,850 h a$ ), 神奈川県 (8力所,

$37,110 h a)$, 埼玉県 (14力所, 79,950ha), 千葉県 ( 3 力所, $75,233 h a$ )

(D) 行楽道路 合計 180 路線, $3,884 \mathrm{~km}$

歩行車兼用道路 東京府 $(44$ 路線, $976 \mathrm{~km})$, 神奈川 
県 (21路線 $660 \mathrm{~km})$, 埼玉県 (15路線, $639 \mathrm{~km})$, 千葉 県 ( 8 路線, $496 \mathrm{~km})$, 遊歩道路 東京府の92路線,

$1,113 \mathrm{~km}$ の他末定

(0) 環状緑地带 合計約 $13,623 h a$

東京府, 神奈川県, 埼玉県, 千葉県の延長 $72 \mathrm{~km}$ に たる環状緑地带

$\Theta$ 大公園 合計19力所 $615 h a$ 大手町, 目黑, 小石川, 後楽園, 荒川口, 羽田, 穴 守, 池上, 洗足, 砧, 祖師ヶ谷, 深大寺, 善福寺, 石神井，練馬，赤塚，西新井，淵江，篠崎地区

\section{表 1 緑地の分類（東京緑地計画による）}

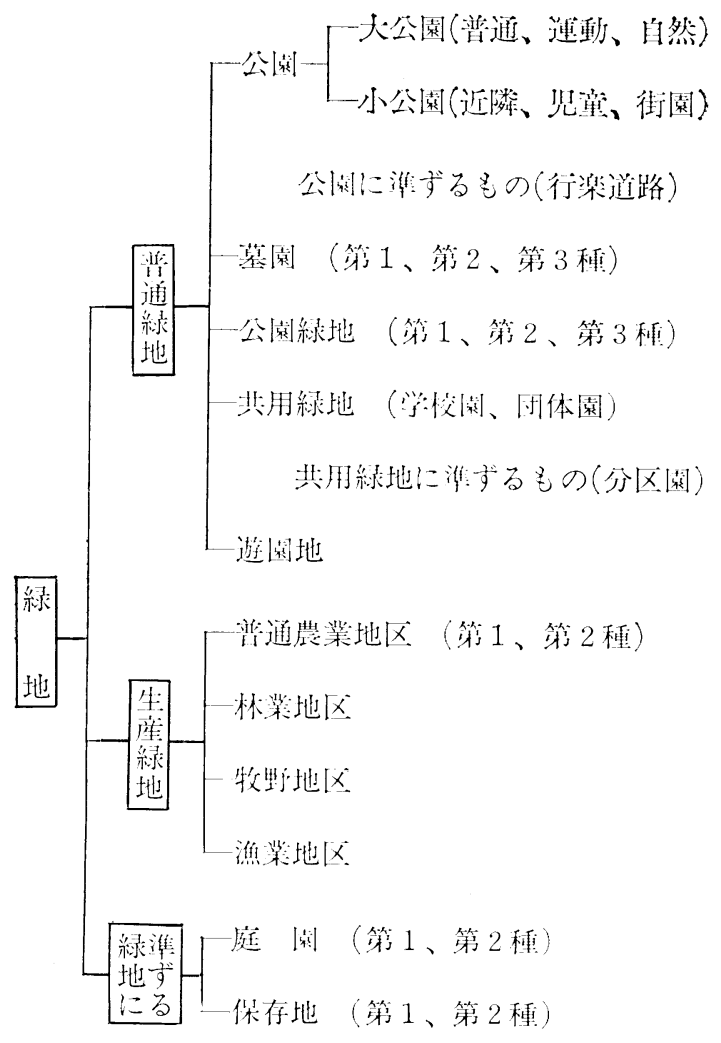

一郆解略化した

\section{过運動場 合計19力所 $626 h a$}

芳浦, 品川, 腚橋, 中野, 野方, 猿汇, 枝川, 鴚' 沢, 二子, 羽根木, 高井戸, 和田堀, 驚, 宮, 板

橋, 汇北, 花畑, 奥戸, 鹿骨, 宇喜田

- 自然公園 合計 2 力所 $440 h a$

大泉, 小合溜

すなわち，この計画の主骨格は，都心より10～ $20 \mathrm{~km}$ 圈: を巾 1 〜 kmで市街地を囲む環状緑地帯である。

なおこの計画には前記の議席をもった人の他に，石川 栄耀, 今正彦, 太田謙吉, 金子九郎, 木村三郎, 塩原 三郎, 長松太郎, 横山光雄らが参画していることを付記 する19)。

(4) 計画の評価と効果

この計画に対する評価は高く，井下は改めて「百年後 には，公園は無くなるであろう」という前言を再確認 し21)，また，小寺は「かつて夢想しえなかった雄大な構。 想」いら評価を下した20)。

またこの時点で特筆されることは, 昭和15年 (1940) 都市計画法改正によるく緑地〉の法定化であり, 従来の 公園とともに緑地が都市計画施設として取上げられるに 至った。

なおここで付言を要することは，大阪ではこの時点で は環状緑地带はなかったが, 後述の防空緑地設定の際に 形態論からみると東京緑地計画より一層典型的な環状緑 地带が策定されており，この計画の骨子は戦後に至るも 放棄されることなく建設が進んでいる。

\section{3. 緑地保全論の系譜 (2)}

東京緑地計画を通じての関係者の研鑚は，緑地論全般 にわたって帚足の成長を示したが，さらにそれが契機と なり，とくに保全上の観点から注目すべき新しい概念が

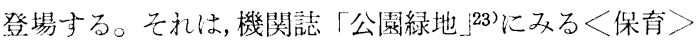
および太田謙吉によるく保全>の用語とその論旨の展開 である。

\section{1 公園緑地協会と保育の精神}

(1) 機関誌にみる保育の内容

\section{表 2 緑 地 の 分 類（太田謙吉による）}

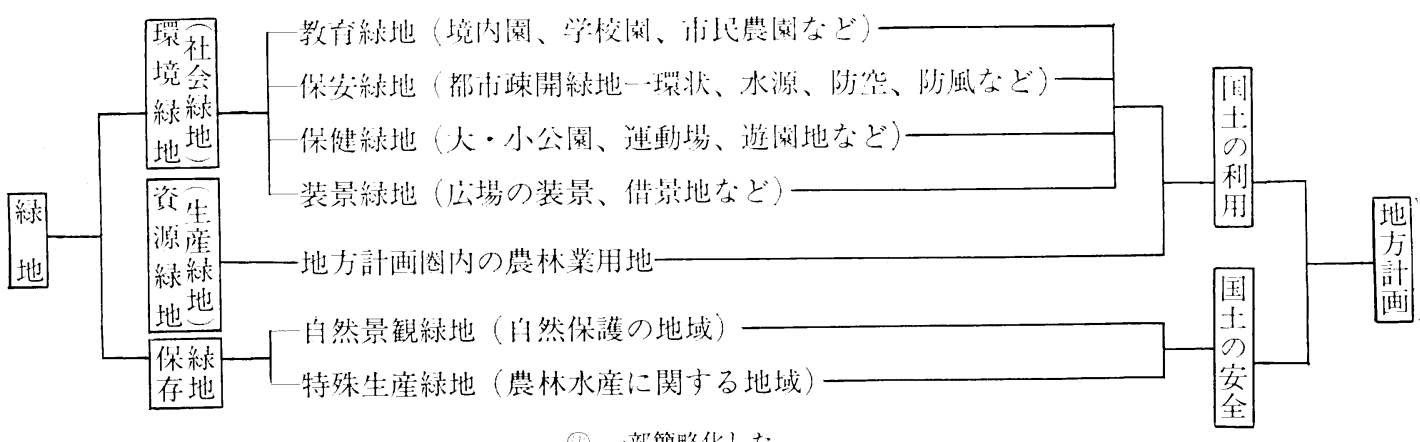

(16) 一部簡略化した。 
昭和11年（1936）11月，「公園その他緑地保育事業の 普及発達を図ることを目的」として公園緑地協会は設立 された。翌12年(1937) 1 月の「公園緑地」創刊号には, 潮恵之輔, 池田宏, 饭沼一省, 挾間茂が巻頭論文 ${ }^{24)}$ で, 都市膨脹の慗害から生じた都市環境の劣悪化を改善する ためには公園緑地の積極的導入が必要で少るという論旨 を述べた。去た太田謙一，北村德太郎，木村三郎，木村

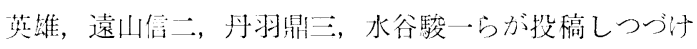
た25)。

この時期に「公園緑地」钆上を中心にく保有する〉と いう表現が随所涀かれていることは特䛉するに值いす

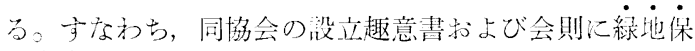
育事業を明示したことは26)，決して不用意な使用ではな く，使用された事例の频度の高さを又ればつざの之おり

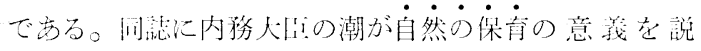

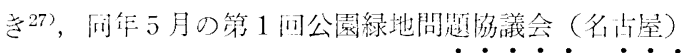

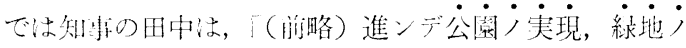
保育习等二進展セシムルコト八蓋ン垷代ノ切区ナル要 求デアル(後略)」之述べ28), 部面課長の真圾忠藏は

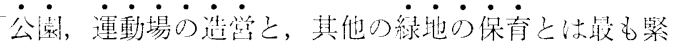
切种要なる文化施没で岉る」というように造学と保育と を别している299。さらに同年 9 月の第 1 回公園緑地講 翼会で沈々の講治科目に「公有林野の保有 (III中八百 八) (30)および「野鳥の保青(内公清之助) 30)があり, それぞれ保充間题を取扱っている。

(2) 木村(桇) 飞よる Landschftspflege の紹介

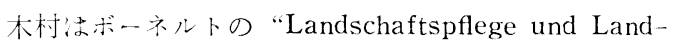
esplanung”を訳して「公塒緑地」に揭载した31)。

ボーネルトの表題からも狸解できるように, 保有の概 仝は-pflegeで㐫り, 従来の保護・保存としての-schutz ではなかったとして，唡者は区別されたものとみなされ る。

つづいて，氏は，H、シュヴェンケルの“Grundzuge

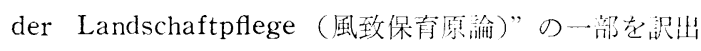
して同訫汇揭載した ${ }^{32}$ 。この論文によれば, 従来誐諭の 的となっていた鄉土保湍 (Heimatschutz) と, 润致保青 (Landschaftpflege) が相反するか否かについて論じ, 著者ショヴェンケルは，保育なる観念は全ての場合に保 護なる観念を含んでいると主張し，両者は相反しないも のである見解を示した。すなわちその関係は，

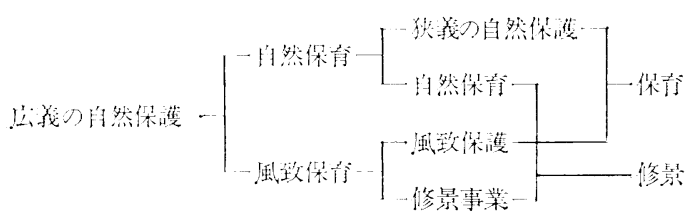

である。

ショヴェンケルはさらに，中世以来ドイッの風土に自 然と人工とが調和と対立をもたらした事例を豊富に示し
た後, (風致にお打る経済性, 口風致汇於ける福祉, 経済と福祉との有機的結合としての地域計画, が問題で 西る之指摘した。当時, 保護と保育に関するこ机活ど峻 效な論文は未だなかったのである。

\section{2 成長期後半にみる緑地保全論}

（1）太田（謙）にみる論旨

一方, 東京緑地計西酒扣いて, 法分としてではないが 公的に緑地の定義が承泪さ机，体制派の大勢がその方針 飞従って夷现化の方何を步几だが，都方計画地方委員の

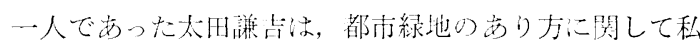
的に考究した結果，顾和13年から装华（1938１939）に

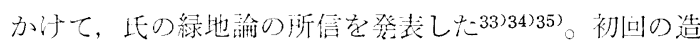
園学会に打ける論文の中で環境緑地〉をはじめとする 各種緑地の名称を用いると之もに，〈保全〉なる名称を

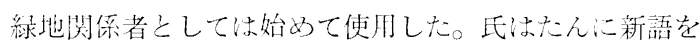
浩ったことにとどまらず，農策行政に招ける䋓地の役割

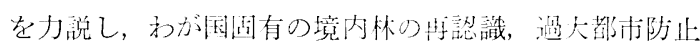

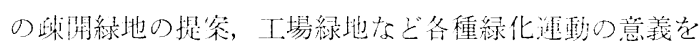
确及した。史た坁の言う環境緑地叔よび资源緑地は国主

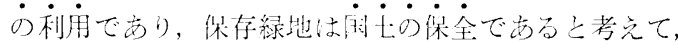

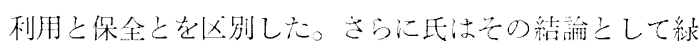
地法制定の必要性を主張したのである。

同じ時期の機関誌「都肪公論」誌上で坻環境緑地の 意義をめぐって與味ぶかい一文を載せている。すなかち

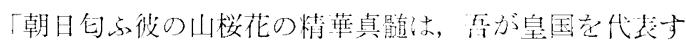
る環境緑地の潅化として, 古来より武上道己立び称せら れ, 常盤の緑の映光は万古不易の民族の推進力に当管 られて，線地の民族に及添せる感伈たるや，亦実に宏大 無辺なるものが岁る」と衣現した ${ }^{35}$ 。

以は:の上らに太帅緑地の思想化ついて体制派の意見 と異るところがあったが，氏自身の人格は最も休例派の 体質に市った。

\section{（2）関口（鍈）の栄績}

関几泣，昭和初年から同17年（1925～1942）にか汁て 数多い緑地問題に阅する諭文を発表したが，なかでも，

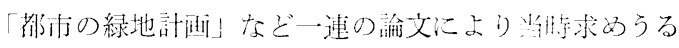
欧米の都市緑地汇関导子思想, 分類, 諸元, 阙基集, 機 能をはじめ，主要国扮よび主要都市に括ける計画事例を

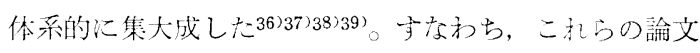
はその1部がさきに日本農学大会で発表したもの之重複 するがさらに新しい知見を入れて充実し，E，ハワード の田園都市， R。 ホイットンの大都市論，A，コミーの 地方計画諭、ロンドンの緑地带をはじる, シンンナチ, ミネアポリス, シカゴ, ニューヨーク， ホストンの公園 系統, ウイーン, パリ，ベルリン，ハンブルク，ケルン の緑地带・都伂林からソビニト・中国の緑地情報にまで わたっており当時の学究はこれにより海外の知見を得, かつ啓発されたのである。 
（3）文化事業としての緑地づくり

皇紀2600年を紀念して日の目は見なかったけれども， 二荒篎德と高山始が唱えた緑地のく文化的意義〉につい ては記憶にとどめる必要がある。すなわち，二荒は昭和 14年(1939), 公園緑地協会の主催する座談会に掠いて, 記念事業として八紘一宇の精神を具現するための国策の 一つとして，神宮内外苑打よび新宿御苑に囲ま机る地区 の緑地化を提案した ${ }^{40)}$ 。それが実現すれば東京の中央部 に全体で約 200ha の緑地が現出して, 他の先進国に劣ら ぬ緑の地茾が開けると主張した。

他方，高川以は昭和15年(1940)，同梾の記念事紧として 東京西方の多糜一门に持よぶ「東京文化林計画」構想を 造園学会訫に発表した。その文化性の意義として，森林 が1)工芸利用としての経済性の促進，(2)国土保安上の使 命, (3)保健休䔩運動など, 森林のもつ全ての文化機能を 総合的に発揮させることを晾らいとしたのであっだ1)。

\section{4. その後の郷土愛護思想の動静}

郷土愛護の思想は，すでに大正期に緑地保全思潮形成 の一要因としての役割を果したが，ここではそのうち，

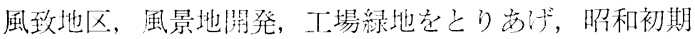
（成長期）の勳问を探ってみたい。

\section{1 風致地区の指定状況}

風致地区法，大正15年（1926），明治神宫内外苑附近 27. 61 ha の指定にはじなるが，その指定が本格的にかつ 全国的に指定された胉期柖昭和 5 年から同11年（1930 1936）にかけてであった。すなおち，间 5 年には東京で 洗足 (30.12ha), 善福步: (60.43ha), 不神井 (93.93ha), 京都で市の東西，北!川川麓 $(3,513.38 \mathrm{ha})$, 熊本で八景水 谷，立田川，成趣園，江津湖，花岡山，万百山，本妙寺 山附近 $(1,069.62 h a)$ であり，つつういて同6年には高松 (242.02ha)，横須賀 $(27.76 h a)$, 同 7 垈に快大阪 (155.68

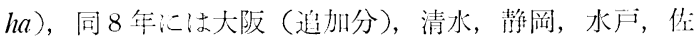

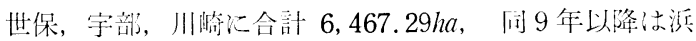

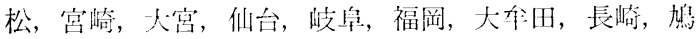
ケ谷, 福息, 大分, 三崎, 高原, 延岡, 宇都宫, 足利, 宇治山田，長岡，豊橋，門司，小含，户畑，八幡，若 松，豊中，富离，大宮(静岡)，観音寺，坆出，香西，多 度津，仁尾，銚了，大津のよらに全国の主要な中小34都 甫の 119 地区が指定された42)

上苔の風致地区の管理運営にあたり，各種の民間団体 の功績を記録にとどめておく必要が市る。京都に沶いて は嵐川保勝会，三保保勝会，京都保勝会があり，東京に おいて咏汇戸川，洗足，石神井，和田堀，多摩川にそれ ぞれ風致協会が誕生した。ここで多攀川風致協会の役割 を例にとれば，との定款に!「風致地区内ニ於ケル景趣
ヨ保育シ風致地区ノ機能 発揚セシム」ことを目的とし (1)保護打よび開発に関する調查研究，只開発事業又は助 成, 仓各種工事, 採取に関する相談, Є動植物の保育, 林来遊者への便宜の提供，講習会等の開催，占関係当 局への建議，を主目的とした。また神奈川に扔いても風 致地区，風景地開発が盛んであり，次節にみる諸団体が 活踓したのである 43/44)45)。

\section{2 神奈川における郷土愛護事業の実践}

(1) 風景地開発事業

当時，風景地開発事業を最も積極的に推進したのは神 奈川䍗であった。昭和11年（1936）県令く風景地開発助 成規程〉を公有，翌12年（1937）に惊く風致樹苗交付規 程〉を制定公布した。この県令は土場緑化事業とともに 同県における緑地関連事業としての 2 大柱であった

風景地開発地区の指定は，さきに策定された東京緑地 計画〈景園地〉を対象とし，大楠山，三崎，鎌食，湘 南, 多摩, 相模原, 大山, 津久井, 晹ヶ原真鶴の 9 地区 が選定された。またこれらの地区では事業の推進にあた 门，民間の多椂な団体，例党ば鎌倉同人会，小由原振興 会などいわゆる保勝会，䘽光協会の結成であり，これは 同時に当時の全国的な傾问でもあった45)

以上の事業の推進は都市部再地方委である太田の力に

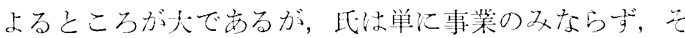
れに関寸る論文をものにし，風景地の開発俨念として，

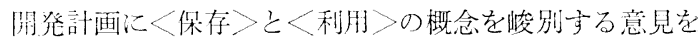
もつと同時に，緦休保存一適正な保存と利用一效果 的利用，という方法を具体的に提案した ${ }^{47}$ 。また，村木 外婎法「風景地阙発計画の体采已其技術的考察」老発表 した ${ }^{48)}$ ここれは前述の太田の諭文とともに, 風景地開発 に開与る卓越した内容をもつものであった。

\section{（2）I場緑化事策}

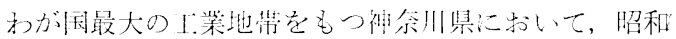
10年（1935）より他照に先がけて厂埸緑化運動の站緹が

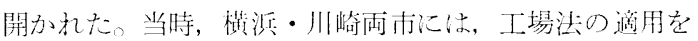
受壮る適格工場数 935, 徉業員数 79,438 人の多数にのぼ り，乙かもわずかの隹まれた企業を除いては悪環㑽の下

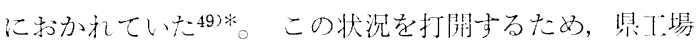

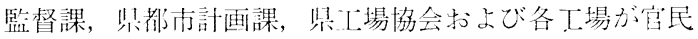
一体となった工場緑化をめざしたのである。

その結果, 昭和写真, 富土フィルム, 芝浦製作所, 千 リン麦酒, 它士通信, 東宗留気, 横浜ゴム, 富土紡績, 日本鉣業，森永製菓（順不䡃）などの各社が十分にその 成果をあげた他，川崎案業，德永ガス，秋用上場，古河 電気，浦賀ドック，富士通信（順不同）の各社が積極的 に県の指導を受け，工場緑化を実践した年511。

工場緑化の提奖は，最初名古屋都茂計画地方委の黒谷

* 当洔京浜地方では10日に 1 日死奴と新聞は伝光た。 
了太郎のく川林都市５2で㐫るといわれているが，昭和 10年段階でよ, 太田謙吉, 丹羽鼎三らが工場緑化の理論 づけを行った。盯なうち, 太田は都市計画的見地上り工 場のみでなく, 一団地の住宅団地経営まで言及し, 田園 都市の理想を折込もことを考觉た53)。丹羽は従業員の環 境亡健康を重視, 緑化施設を具体的几提示 (緑陰, 薣芸 溒, レクシエーシ・ョン施設), 結論として既成「場の緑 化でなく，計画当初から緑化施設を盛込むことにより，

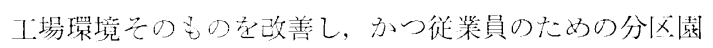
など厚生施設堂るつこと提案した ${ }^{54) 。 ~}$

以上のように，当時は1企業志対像としたて埸緑化の 呼称がようやく普及しはじめ，かつ住局対策まで言及は したが，今日いらインダストリアルハークの発想にもと ずく多企業の参加による工境四地の着想はなかったとみ てよいで䏮ら。

\section{5. 函館市の防火都市建設事業}

昭和 9 年 (1934) 3 月 21 日, 津軽海陕の西方洋上に風 速 $24 m$ の台風が北上してい万最中の 6 時53分, 函館市住 吉町の民家より火在発生し, 翌22日朝究でに, 同市面積

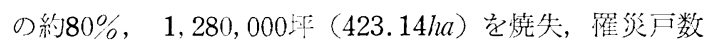
22,667世带, 死者2100余名の大惨事となった。函館の市

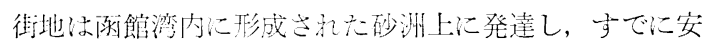
永 7 年（1778）飞炎荻が記録されて以来，火苂の発生し やすい自然条件下汇唡り, 明治以来今回の大火に至るま でに多くの大火が発生し，昭和に入りとくに消防設㒉の 改善をはかってきた都市で苛っだ5)5657)。

同市を恒久的な防火都市として復興与るため, 同月末 までに内務省上り担当者が出張し, 北旅道片, 函館市の 関倸者とともに復興計画の立案にかかり, 大火後 2 旬を 絓ずして第 1 回の都市計貍地方委員会を閏くまでに進捗 した。地方委で中心となって調查・計两を担当した関倸 者は, 神保金衛, 村上幾一, 䘞屋守次, 田中彦敏の諸氏 であった ${ }^{58)}$

復與計画の基本万針告，1地域制の確立，(2)都心地区 の設定，(3街路の後㦛，毛防火地区の設定，(5)屋上制限 令であった。すなわち, 1の地域制に関しては, 工業地

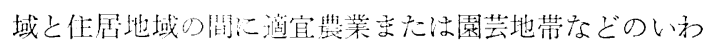
ゆる利用緑地觉設ける。2 の都心地区に関しては建築物 の前庭, 後庭㧍よび街路樹木を相市わせて緑地として抎 大させる。以上が緑地関倸ある方針であった。この方 針は上述の都市計画地方委員会に和いて審議されたが, その後数次にわたる計画案の追加変更を行ない, とくに 緑地関係の最終決定はつぎのとおりであった ${ }^{57158) 。 ~}$

第 1 公園 住吉町地内 面積約 $0.62 \mathrm{ha}$

第 2 公園 大森町及 千才町地内 $\}$ 面積約 $3.56 h a$

第 3 公園 新川町地内 面積約 $1.12 h a$
ただし，以上の 3 公園は既設の函館公園3.16haを合せ てもその面積はわずが25,600坪（8.46ha）であり，燒 失区域全面積との百分比汸ずかに約 $2 \%$ にしかすぎな かった56)。

しかるに隶館都市計画化扮沙る防火都市としての配慮 は，その基本方釗にみられるよらに広路に設沙られた緑 地带と公園とが渾然と一带となり, さらに農業, 園芸地 带を毛包含して総体的に緑地としての機能を高めようと

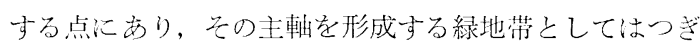

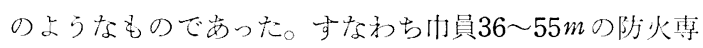
用街路（緑地带付）を大体700 800 m 間隔に格子状㳊没 け, 防火専用街路の交文点汇公園, 緑地, 不然建築物を 設けることであった58。

以上の大事業を実施するために，約 $150 h a$ の面積に公 園 5.3ha, 幹線・補助幹線の総延奏約 $90 \mathrm{~km}$ 学昭和13年 （1938）までの5力年間に完成したのであった。そして それ以後，大火で知られる济领から，大火はまだ一度も でていないのである59)。

\section{6. 防空緑地の思想とその推移 \\ 6. 1 防空緑地への道程}

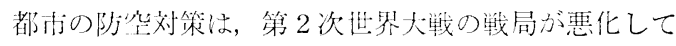
から整储された印象を与光ているが，との思想はすでに 䀔和の初期に之の端を発している。与なわち航空機によ る都市爆撃は第 1 次大戦〔大正 $3 \sim 7$ 年(1914～1918)] に行われ，欧米交戦国は急きよ防等対策を実施したが，

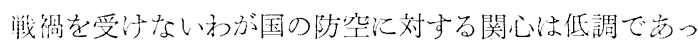
た。昭和 3 年 (1928) 軍部は, わが国初の防空演㥜を実 施, 都市防空への啓蒙宣伝を行い, その後, 名古屋, 北 九州，東京など昭和10年までに56都市に史施した。しか 乙当時はまだ防空緑地といら発想はみられなかった60)。

以上のような防空の啓蒙気運が高まる中で，明和 8 年 (1933)，代議士江藤源九郎らによって，〈防空施設促進 二関スル建議〉がなされた。法案は陸・海・内務などの 各省間の調整に年月を要したが，昭和12年(1937) 3 月， 防空法は制定された。すなわち第1条「(前略) 陸海軍 ノ行フ防衛二即灾シテ陸海軍以外, 者ノ行フ灯火管制, 消防, 防毒, 避難及救護亚二此等二関シ必要ナル監視, 通信及警報习防空計画卜称スル八防空, 実施及之二関シ 必要ナル設備又八資材, 整備二関スル計画习謂つ」と意 義の゙けている60)

すでに満州事変よりアメリカ，ソビエトが仮想敵国之 なり，上記の防空法案が審議されている最中，一方では 東京緑地計画が立案中であった。この緑地分類の中にも 防空緑地の概念はなかったことに，注目すべきであ万う （ただし軍部から委員は出ていた）。防坚法の制定直後 の昭和12年 (1937) 7 月, 盧溝橋事変が発生, 大陸汇戦 雲が広がっていった。 
防空に関する認識が軍民の関係者で真剣に考兄られた のは，欧州汸汁る航空戦によってである。昭和15年 (1940)ドイッ空軍による英本土への攻撃は, The Battle of Britain として知られているが，とくに都市防空上か らの関心は同年 9 月 7 日から57日間にわたって続けられ た首都ロンドンへの昼夜間爆撃である。この爆撃によっ て首府の主要部は廃墟と化した汇もかかわらず，耐火構 造からなる同市の都市活動は停止しなかった61。

この戦即がわが国の防空関係者へ与えた影響は実に大 きかった。元来, 四周海洋の防借線をもつふが国にとっ て, 都甫の防借钼念が薄く, かつ致命的にも家屋の大半 は木造からなり，都市構造は他のいかなる近代国家のそ れよりも少っていることは明かであった。

本来，都市防空は积極策としての軍防空㧍よび消極策 としての民防空からなり，軍は〈攻撃は最良の防禦なり〉 との姿勢を堅持したが，昭和16年（1941）1月，山下奉 文らの欧州視察団に上り，民防空対策は急速に進展吉る ことになった60)。

\section{2 防空都市の思想}

民防空として都市の構筑を担ら分野, 与なわち土木, 建築，造園の都市防空汇関与る思想を大別与ると次の上 らになる。

土木界の見解は石川栄躍によって代表される。その論 旨は, 都市の構造を空襲から完全汇防顀することは不可 能で劣る。したがって大都市においては䠅開の実施（人 口の分散）により被害を僅少にすることが朋要である。 この見解は単に都市防空の手段を考えたのではなく，石 川の国土計画上の主張との関連性があっての発想でも西 万(2)63)。

建築界の見解は田辺平学によって代表される。乞の論 旨は, 都市の不然化, 与ならら耐火・耐震構造によって 被害を最小限に位止めようとするものである。この見解 法都市防空の見地から強調はされているものの, それは 大震災からの悲䝠である燃えない都市べくり論の再登場 でも㟧った ${ }^{6465) 。 ~}$

造園界の見解は太四謙吉, 例東五郎, 水谷駿一らによ り述べられているが，ての根底に做架を通じての緑地

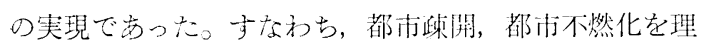
想としながらも，それらの恒久対策が早期に夷現する見 込が暗いため，市街地が被爆した場合，その延焼を最小 限に食い止めようとすることであり，炎の手段として緑 地带・空地带らのオープンスペースがく防空緑地〉とし て登場してくる。また防空緑地は㔖くまで非常時対策で

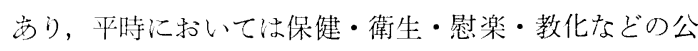
園利用㳊資寸るとい5多面的効用を考光ていた ${ }^{66667) 68) 。 ~}$ 防空緑地に関与る論文は，昭和15～18年（1940１943） にかけて，機関誌「都市公論」「公園緑地」に称の打の 数篇が掲載され, 関係者への啓蒙をはかった他, 「造園

\section{雑誌」にも散見された。}

\section{3 防空緑地の実現へ}

昭和16年（1941）11月25日，すなうち太平洋戦争䜞始

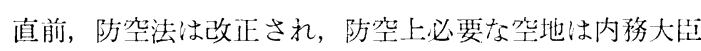
が直接指定できるようになった。太平洋上の緹戦そのも のは，わが国に有利に展開されたが，昭和17年 (1942) 4月18日，米軍ドートリットルの率觉るB25により，日 本本上は初めて空㜪を受汁心。前述の防空緑地は調查の 段階に㘯ったがこの等壟が警鐘となり，翌18年 (1943) 3 月30日, 東京㧍よび大阪に防空緑地が誕生することに なった。

防空緑地は止式にはく尘地带〉およびく防空空地〉か らなる。空地带は環状沶よび放射状の空地带により構成 されるが，その唒渭はつぎの市街地模成に適合寸るもの

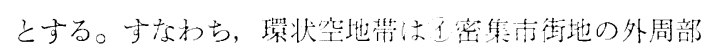

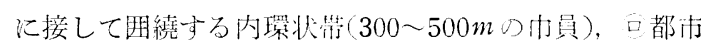

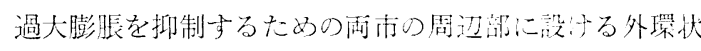

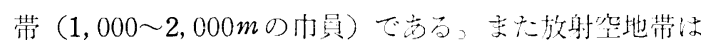
内環状带から不都心に向って楔入正る内放射带（100 $150 \mathrm{~m}$ の巾員)，正外側汇向って楔入王万外放射州（300 〜 $1,000 \mathrm{~m}$ の巾員) である。防空空地は，11団の”地 で1, 000坪 $\left(3,300 \mathrm{~m}^{2}\right)$ 程度以上, 互 1 団の空地で 500 1,000 平 $\left(1,650 \sim 3,300 \mathrm{~m}^{2}\right)$ 程度のものでいずれも内政 状空地带の内側配置与るものである。な就記の方剑

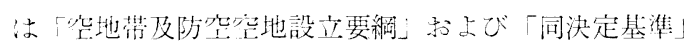

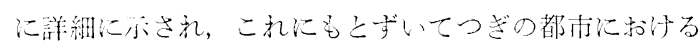
空地带㧍よび防空空地は同18年（1943）3月30日指定さ れた69770。

\begin{tabular}{|c|c|c|c|c|c|}
\hline \multirow{2}{*}{ 都的多 } & \multicolumn{3}{|c|}{ 赖 } & \multicolumn{2}{|r|}{$\therefore$ 政 } \\
\hline & 地州数 & 活问 & 抟 & 纨勒恢 & 程 \\
\hline (地带) & (力游) & (厂胡) & tha & & Fit ha \\
\hline 讨能射带 & 3 & 3636 & 114,4 & 4 & $=-0$ \\
\hline 外放射带 & 8 & 6,0756 &,$(111,2,2 ?$ & I & \\
\hline 内摆状带 & 8 & 3,2606 & 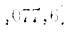 & r & $-3,0 \pi, 8$ \\
\hline 外環状带 & 4 & 18,8356 & $2,22,4$ & ร & $(14,5010,6,402,7)$ \\
\hline 小战 & 23 & 28,532, & 432,1 & $1:$ & $2 \cdots+0,2(7,810,7)$ \\
\hline 附空地地 & 285 & $1,038,8$ & 323,4 & 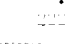 & $014.8 !$ \\
\hline 令 却 & & $29,570,8$ & $(1,5,5)$ & & $29,242,8(8,1313,9)$ \\
\hline
\end{tabular}

*为所效

\section{表 3 東京・大阪の防空緑地（S. 18.3.30）}

つづいて同19年（1944）1月26日, 東京㘧よび名古屋 に执いて改正防空法第 5 条にもとずく频開空地地带が指 定された。東京の踈開空地11力所, 93, 765坪（309, 900 $\left.m^{2}\right)$, 空地带 4 力所, 95,270 坪 $\left(314,900 m^{2}\right)$, 合計 15 力 所, 189,035 坪 $\left(624,800 \mathrm{~m}^{2}\right)$, 名古屋心疎開空地 4 力所, 95,200 坪 $\left(314,700 m^{2}\right)$, 空地带 4 力所 96,300 坪 $(318,300$ $\left.m^{2}\right)$, 合計 8 力所, 191,500 坪 $\left(633,000 m i^{2}\right)$ なお, この時 


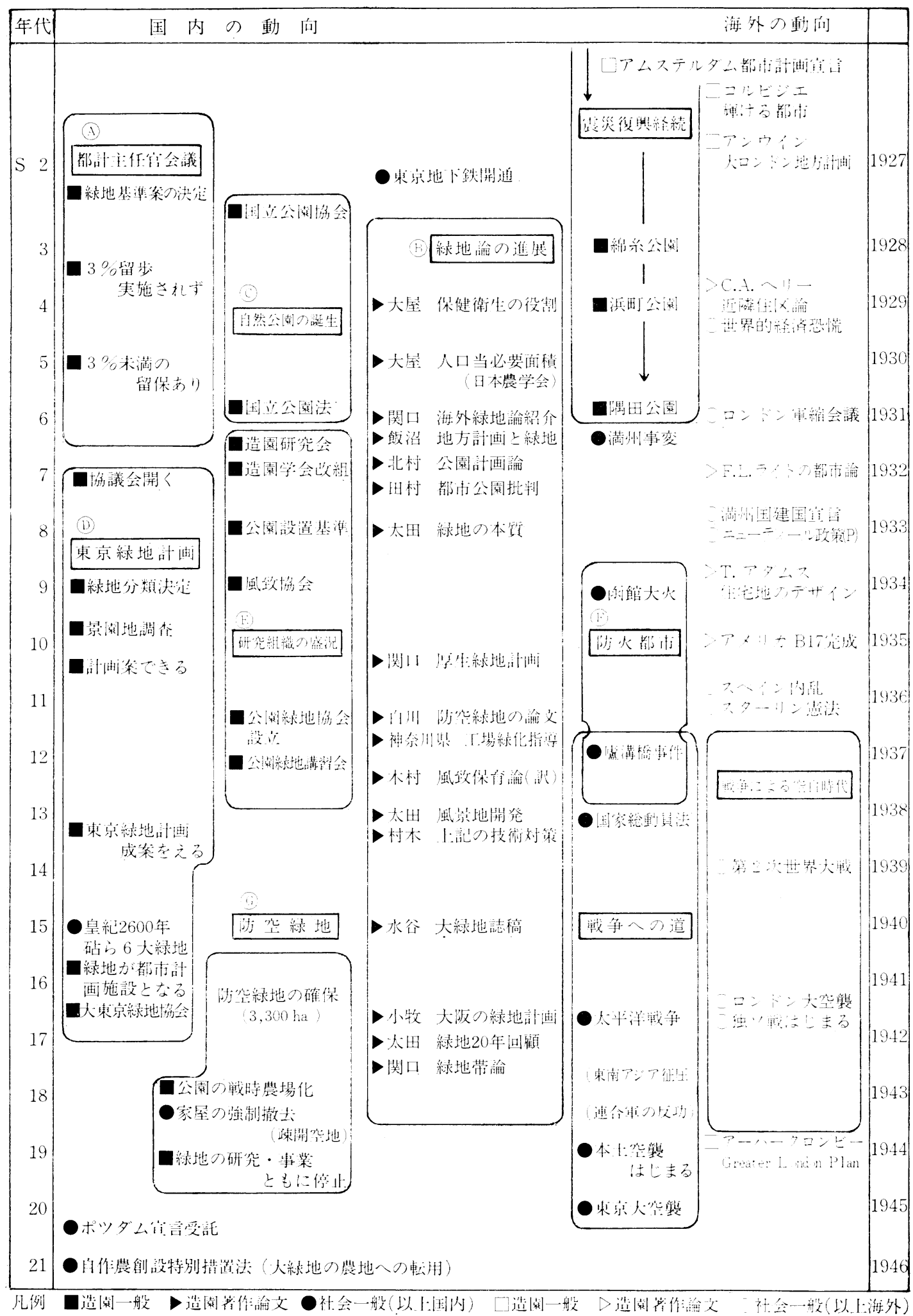


点で横浜, 川﨑, 大阪, 神戸, 尼ヶ崎, 小倉, 阴司, 八 幡, 戸烟, 若松の都市沁おいても, さらに東京, 名古屋 の追加についても同法の適用を受けるべく準備が進めら れだ。

昭和18年 (1943) 日本本土は1回の空繁当受けなから たが，同19年（1944）6月には，米空軍は中国大陸か らB29による北九州の染整を阙始した。4大」業地带の 他, さらに横浜 (62力所), 川揢 (23力所), 横須贺 (41 力所), 四日市 (11力所), 広島 (133力所), 谷 (85力

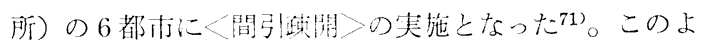
らにして主要鄚市の間引理開が急速に実施はじめたが, 一方米軍は同年末アリアナ諸島を占領とすると同時に， これを基地として，日本全域を爆撃の対象とした。

すなわち, 同年11月24日の東京空襲にはじまり, 翌日 には九州各都市, 12 月に入るや名古屋, 浜松, 清水の東 海地方が爆撃された。翌 20 年に入り 1 月には 9 日間, 2 月には11日間，3月には13日間と米空軍は爆撃の手をゆ るめなかった72)。このううな状況下に，わが国の中小都 市まで間引踈開により被害を最小限浪い止めるよう努

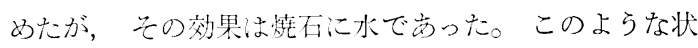
況の中で，昭和19年後半から同20年前半にかけて機関誌 「都书公論」「浩園雑誌_,「公園緑地」,「武藏野」は他 の諸雑誌とともに全て休刊定余儀なくされた。

また戦㷋史上，緑地保全の視点から重要なことは，関

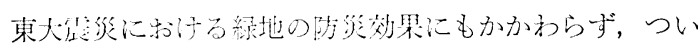

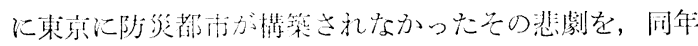
20年（1945）3月の東京大算の被害にみることができ る。すなわち3 月10日米肳, B290大緗隊は奇しくも,

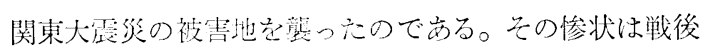
〈東京空襲を記録する会〉により，正確なかつ生々しい ドキニメントとして刊行され，ぼう大な䍜災の記録が収 められている。なかでも注目觉ひく事は，防災対策なき 都市への報いとしてか, 大震贸之同椂 8 万余人の都民が 犠牲となった事奏で西ったで273)。

\section{7. 考 察}

(1) 成長期に䄧沙万保全の立場について

成長期之い光ども，研究・行政の各分野ともに自立乙 た保全部門が市ったか子ではない。しかし研究論文, 各 種の緑地計画の中に保全上の配慮が何光るようになる。 たと党ば，保護・保存に関して保育・保全の概念が生れ たり, 東京緑地計画に法かに郷土愛護, 都市膨脹規制 の意四が現われていた。また函館では防火都市づくりが 実现し、防空都市らくくり着手されたのである。したが って,こうした時期の中に, 十分ではないが一貫した保 全思潮を見いだしらるであらら。

(2) 緑地論の争点について

都市で必要とする公園面積は, 萠芽期ではもっぱら市
街地面積の $10 \%$ 説が有力な意見であったが，成長期の初 め, 大屋が人口当りの必要面積を主張して以来, 大勢が それを支持することになり，今日に至ったことは，成長 期の成果の一つであるとい光る。

（3）主任官会議の $3 \%$ 説について

都市計画主任官会議に拈沙る緑地基準として, 地区の 3\%以上公闎として留保することを決め, それが今日に 至った事実をどう評価すべきであろうか。(1)前述の大屋 説以解の決定であるとはい⿱, 市街地に対して一律に 3 \%と決め, 人口当りの算定法をとらなかったことは惜し まれることである。しかし，3\%の意味が正しく認識 されなかったことも事実である。といらのは基準には3 \%以立之明示されている。すなわち，3\%は最低基準で あって適正值ではないのである。

(4) 緑地の分化之派閥の形成について

都市の緑地之国土の自然は明かに性格, 規模, 計画手 法, 管理方法の諸点について明かに異るから, 造園界が 両者に分化することには必然性がある。しかし，それが 原因で両者に派閥を形成する必然性はないはずである。 領域の分化と派閥の形成を泥同すべきではない。ところ が両者の対立は神宫造営以来といわれるように依然とし て緭いたのである。

両者が 2 度にわたって交流を奏施したことは，それな

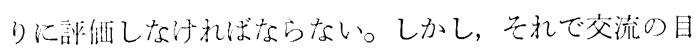
的が全らされたかどらか疑問は残るのではあるまいか。

(5) 東京緑地計画の役慗について

この叶阿は, 必ずしも保全上の観点が主体ではないが

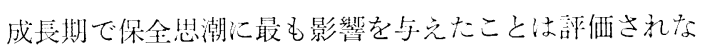
ければならない。とくに環状緑地の思想を強く打ちだし ている点アムステルダム会議に影響されたにせよ, 都市 の膨脹規制をはかる上から有効であった。また反面, 放 射状を過少評洒したのではなかららが，それにしても放 射状は環状へのアプローチとなるから，放射状への強い 资勢があってもよかったのではなかららか。それとも放 射を確保する立地上の余地（土地）がなかったのが現実 の姿であらうか。

（6）保育・保全の用語について

公園緑地協会の設立直後, 緑地の保育という呼称が盛 几使われたけれぞも，それは日常葀として一般社会へ 浸透する影響力まで持ってはい沈かった。そして二三年 で関係者の間でも使用する頻度は非常に少くなったのは 意外であった。用語が適切でなかったのか，それとも戦 時態勢という時局が先行して関係者へそれを吸収する余 裕を与学なかったか，その辺は不明である。

しかしここで重要なのは，大田，木村の論文にみられ るよらに, 利用と保全, Schutz と Pflege の立場がその 時点で明確になってきたことである。大田が保育を用い ることなく保全を用いた理由は判然としないが，当時氏 
が地方計画的な思考をしていたことからすると，国土的 な広がりに対して积全がより適切であったのではない かといら推論ができよう。また木村の用いた保育 Pflege そのものは，造林学では大正時代から用いているが，造 林上法林木を対象とした Erziehung が多用され，土地 を包含した Pflege は特殊な使い方をしているように思 われる。したがって，緑地で使ら保育は Landschaft の Pflege からの発想と又てよいのではなかららか。

(7) 郷土愛護思想のその後について

全ての分野にわたって保全思想が倾調化成烄していっ たわけではない。風致地区沉ついては地他の指定の段階 を迎光たが，前期に活躍した武藏野会は会員も減少し， 趣味の会に徹し，保護・保存，保全の桨勢は強いとは言 克なかった

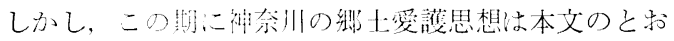

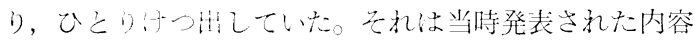

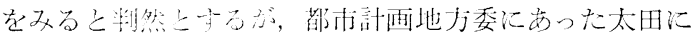
努力に上るもの上观られる。郷上爱護運動は全層のレベ ルアッフ上亡もに，有能な 1 人のりーダーの力を示した 一例と灭るこ上ができよう。

(8) 防火都市について

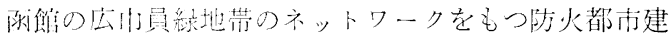
設は, 都市計画上加名ても, 緑地計画上から女ても快 挙といいらるであるら。しかし，何故そ礼は函館の久に とどまったので毒万らか。その理由は，決して単一では ないが，防火防苳上から重要なことは，防ぐ都市つくくり

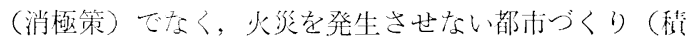
極策）への転換を必要としたことが指摘できる。それは

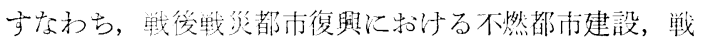
後新設された数々の大規模二ュータウンに棋極的な耐火 建築の出現に主因がありそうである。それらの程極的な 防災対策の䋨果，思想的にはオープンスペースにより火 災を防ぐといら役割は，全しろ戦角より低調になりつつ あること告めない。

(9) 防空線地について

緑地関係者は防空緑地といい，軍関俰者は防空空地之 いら。吕の相连は部局による対立ではなく，平時利用か

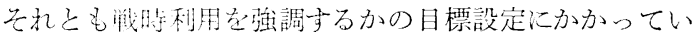
た。大峨名分としては戦時利用であるが，軍民とも戦時 利用がひんぱんになっては迷惑である。結局，防空予算 に上り実施されたが，その内容は東京緑地計画を骨子と したものに他ならない。关れは，環状緑地と環状空地带 の相似性，类た東京緑地計画協会が防空空地協会に看板 をか觉た経過からみてる明膫である。皮肉な結果である が，平時では，いつ実現できるか予測のつかない遠大な 計画が戦時態勢といら力によって，その一部が実現され たのであるが，敗戦とともにとの事業は挫折したのであ る。

\section{引用 文 献}

1）大屋显城「衛生施設としての公園の価值」都市公論 $12 \cdot 1, \mathrm{~S} 4$

2）同上「都市の公園面積」都市公論 $13 \cdot 8, \mathrm{~S} 5$

3）永見健一「(理論・実践) 造園学」盖賢堂，S7

4）関口鍈太郎「現代都市公園面積に関寸る各国の学 説」日本農学大会, S6

5）北村德太郎「公園は何故必要となるか（日本都市に 拈计る公園計画)」都市公論 $14 \cdot 8, \mathrm{~S} 6$

6）同上「公園とは? (慰楽園地の分類)」都术公諭 15 $3, \mathrm{~S} 7$

7）同上「都市の公園計画一応の理論」都节公諭 $15 ・ 12$

8）田村 剛「都市公尉に関与る三三の考察」都市公諭 $15 \cdot 8, \quad \mathrm{~S} 7$

9）厚生省国立公㵏部「日本の国立公㕑」同省，S26

10）本村三郎〔インタビュー一施録さ】1951

11）日本造園学会事務局资料

12）曰村 剛〔インタビ二一記録 1〕 1950

13）石神甲子郎，小牧立夫，石原耕作の諸氏より直接確: 垫を克た

14）主任它会睋記録 都市公論, S2

15）西整理施行面䅡並公塬保留地 公園緑地，S2

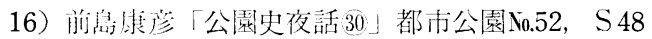

17）「東京緑地計画特集号 - 資料」公園緑地 $3 \cdot 2 \sim 3$,

18）「東京緑地計画議事録」S9

19）木村三郎，本多作の両氏からのヒアリングによる

20）井下清「公園より緑地一」公園緑地 $6 \cdot 2, \mathrm{~S} 17$

21）小寺酸吉「時局下造園界の諸問題」造園研究 $\mathrm{N}_{0} .36$, $\mathrm{S} 16$

22）「大阪府公園緑地配置計画図」による，S19

23）「公園緑地」同協会，S12～(S19２1中梀）

24）「公園緑地」 $1 \cdot 1$ 亿潮「所感」，池田「自然之人文の 調整を目指与明日の都市計画文明へ」，飯沼「都市に 於汀る自然の欠乏」，摤間「都市衛生と緑地」S12

25）S12〜20委でに緑地関係について 2 篇以上揭載

26）公園緑地協会設主趣意書出よび同会則，S11

27）潮恵之助 24）に上る論文

28）第 1 回公園緑地問題轿議会（名古屋）S 12.5

29）真坂忠藏「近代都市の公園汇就て」公園緑地（名古 屋特集号) $1 \cdot 1, \mathrm{~S} 12$

30）第 1 回公園緑地講咟会（東京） S 12.8

「S 12

31）木村英夫「風致の保育々地方計画」公園緑地 $1 \cdot 9$,

32）同上「風致保育に関する一般問題」 $30 \cdot 10, \mathrm{~S} 14$

33）太田謙吉「地方計画之緑地問題」造園雑誌 $8 \cdot 1, \mathrm{~S} 8$

34）同上「緑地の本質に就て」造園雑誌 $8 \cdot 1, \quad \mathrm{~S} 8$

35）同上「地方計画と緑地」都市公論 $22 \cdot 2, \mathrm{~S} 14$

36）関口鐄太郎「理想の都市計画」造園学雑誌 $2 \cdot 9$

37）同上「都市の緑地計画」造園研究 No. 3， 4, S 7 
:38）同上「厚生緑地計画」造園研究， S10

39）同上「緑地带」公園緑地, S 17

40）二荒芳徳「緑地問題座談会」公園緑地 $3 \cdot 2 \sim 3, \mathrm{~S}$ 14の中に打汁る発言

41）高山始「東京文化林計画」造園雑誌 $7 \cdot 1, \quad$ S 15

42）「風致地区一覧表」公園緑地 $1 \cdot 1 \sim, \mathrm{S} 12$

43）水谷駿一「帝都の風致地区に就いて」都市公論 16 • $2 \sim 4, \quad$ S 8

44）京都府「風致地区に就て」同府，S9

45）神奈川県「風景地開発座談会」公園緑地（神奈川県 特集号) $2 \cdot 4, \quad \mathrm{~S} 8$

46）神奈川装「風景地開発助成規程」同目 S11 および 「風致樹荫交付䙺程」同県, S12

47）太目謙吉「風致地区の管理経営と風景地閒発助成規 程との関連汇就て」公囯緑地 $2 \cdot 4, \mathrm{~S} 13$

48）村木外雄「風景地開発衙四の体系之其技術的考察」 公園緑地 $2 \cdot 4, \mathrm{~S} 13$

49）東京朝日新聞 神奈川版苔事, S12.6.10

50）横山喬「本県に於沙万工場緑化の概況」公園緑地 $1 \cdot 7, \quad \mathrm{~S} 12$

51）「土場緑化写真集」公固緑地，同上

52）黑谷了太郎「山林都市（林間都市）」T11

53）太田謙吉「都市計画と工場緑化の地位」公園緑地 $1 \cdot 7, \quad \mathrm{~S} 12$

54）丹羽鼎「工場緑化汇関与る考察」公園緑地, 同上:

55）圂館消防本部「圂馆大火史」同本部，S12

56）日本建築学会「函館大火災」建築䧱誌，S9

57）计政調查会「囦館市の復興計画汇就て」同会，S 9

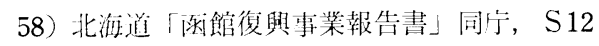

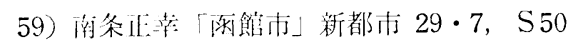

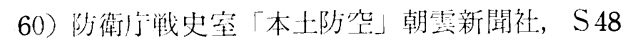

61）当時の新间に外電を通じて豊富なニニースがある

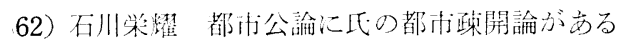

63）同上「国上計画（生活圈の設计）」S17

64) 田辺平学「不燃都们の建设」方政調查会

65）同上，同主旨の論文が工業俱楽部からでている

66）太田謙吉「時局之緑地」都术公論 $23 \cdot 1$ S 15 他

67）伊東五郎「独逸都市計画視察の印像」公圆綠地 6 $1 \sim 5, \quad \mathrm{~S} 17$

68）水谷酸一「防空大緑地の設計理念註つて」造園雑 誌 $8 \cdot 2 \sim 3, \mathrm{~S} 16$

69）木村英雄「防空空地及び空地带の指定」都市公論,

70）「防空空地汇関する座談会」公圆緑地7・4，S18

71）「都市公論」「公園緑地」のニニース欄よりひろう, S 19

72）建設省「戦災復興誌(第 1 卷) 都市計画協会, S 34

73）東京它唯を記録する会「東京大空襲」講談社，S50

\section{Summary}

(1) Enlargement of green space through land readjustment

The seventh item of Green Space standard determined by Supervisory Committee on City Planning in 1927 states that more than $3 \%$ of urban area should be reserved for green space. This was significant in the sense that green space was obliged to be newly constructed.

(2) Greater Green Space Plan in Tokyo

The fact that in Europe the necessity of green space has been stressed at earlier time by Green Space Plan in Berlin (in 1911) and IFHP Congress in Amsterdam (in 1924) influenced the promotion of establishing Tokyo Green Space Council. It prepared a Greater Green Space Plan in Tokyo based on environmental green space as the result of 8 -years research. However, this plan was interruped during the construction processes and never realized because of the defeat on World War II. Besides this plan in Tokyo, there was environmental green space plan in Osaka.

(3) Hakodate Great Fire

In 1934 Hakodate where had been notorious for fires was heavily damaged by a disastorous fire. As the countermeasures against fires, Hakodate City constructed the Network of Green Belt, fine prevention zone, in order to build a fire prevention city. It was the first appearance of fires prevention city in Japan. Later than Hakodate has never been visited by a big fire.

\section{(4) Open Space for Air Defence}

It is commonly said that open space for air defence was planned for its construction at the last part of the World War II. However, concerned agencies had actually planed air defence cities before the World War II. At that time since Japanese houses were made of wood and papers, it was more essential to have countermeasures of air defense. The open space for air defence itself was not more than the plan in corporating the most of Tokyo Green Space plan which had already been authorized. It was interesting that the Greater Green Space plan was eforced for its execution by countermeasures of air defence.

Entering into 1944, the air raid by the Allied Forces became much more violent. At the end of the War about 120 cties and 2 million houses were destroyed by bombing. 